\title{
Can Toponomastics Explain the Origin of Crusader French Lexemes Poulain and Turcople?
}

\author{
HENRI DIAMENT
}

\begin{abstract}
A
MONG THE LEXICAL ITEMS created by speakers of Old French outside the limits of their homeland in what may be described as an early instance of colonial French one finds, inter alia, two words whose meaning is quite clear but whose etymology has never been satisfactorily explained: poulain and turcople. Both appear in the lexicon of the Latin Kingdom of Jerusalem and subsequently spread to the mother country, their semantic referents being, of course, directly linked with the situation in the Holy Land and other Crusader establishments in the Eastern Mediterranean. The official language was that of the majority of the Christian conquerors: Old French and to a lesser extent Old Provençal. Poulain, in its earliest attestations spelled polain or polein, ${ }^{1}$ is usually glossed as "Enfant né du mariage d'un Franc et d'une chrétienne d'Orient." It may well have started out as a sort of nickname ("colt") but came to acquire a meaning close to that of a patrial to designate Palestinian Frankish natives in general. A secondary semantic evolution is discernible: from a term of endearment it evolved into one of contempt. ${ }^{3}$ At any
\end{abstract}

\footnotetext{
${ }^{1}$ While the first "literary" attestation of the term is found in Joinville's biography of King Louis IX (Saint Louis), according to A. J. Greimas (see note 2), in a quotation, dated 1272, to be discussed infra (see note 46), earlier references exist: Joshua Prawer, in what may well be the definitive History of the Latin Kingdom (Histoire du Royaume latin de Jérusalem, 2 vols., Paris, 1970) implies that a Latinized version PULLANI was already in use in 1148 (Vol. I, p. 386) and definitely states that it is attested as such in 1216 (Vol. II, p. 135). While, in the former quotation, Prawer equates "Poulains" with "noblesse indigène," in the latter he gives us a capsule semantic history of the lexeme: "Pullani-terme péjoratif désignant les indigènes. Il signifiait probablement au début 'poulain', né en Terre Sainte, mais on le prit bientôt dans le sens de bâtard" (note 8, loc. cit.). But see also note 6, infra. 'A.J. Greimas, Dictionnaire de l'ancien français jusqu'au milieu du XIVe siècle (Paris, 1969), under the third entry of polain, p. 500 .

"Such a semantic evolution is not unusual in the history of colonial settlement in various parts of the world. In eighteenth-century America both Yankee and colonial, forms evolved to distinguish native sons of the New World from their immigrant forebears, were used by the British with a shade of contempt even though referring to people of the same stock. Cf. also the Pieds-Noirs, i.e., the French of former colonial Algeria, as the term was used in metropolitan France in the sixties when most of them were "repatriated" following Algeria's independence. Mutatis mutandis, a similar phenomenon seems to be taking place in the very same locale that saw the evolution of poulain, some seven to eight hundred years later: Native-born Jewish settlers in Palestine, even before the formal founding of the state of Israel, came to be known as Tzabras ("Cacti," referring symbolically to a gruff exterior
} 
rate Greimas, among others, states that its origin is obscure.

At first glance the other word would seem to have nothing in common with poulain: turcople, attested from the twelfth century, ${ }^{5}$ referred to a lightly armed "Turkish," i.e., Moslem (whether actually Turkish or not) soldier serving with the Crusaders as auxiliary. Its etymon, however, is almost as obscure as that of poulain and one gathers from the literature an impression of intellectual malaise on the part of scholars trying to account for it, for instance T.S.R. Boase. ${ }^{6}$

As is the case with the bulk of etymological problems, absolute proof of any hypothesis propounded to account for the obscure origin of such terms would be hard to come by, unless new attestations with the appropriate explanatory context happen to see the light of day. While not wholly impossible, such a situation is most unlikely to occur. But this does not mean that hypotheses should not be proposed, and in the absence of certainty a high degree of probability may be attained if the hypothesis is plausible on phonological, morphological, semantic, graphemic, psychological and historical grounds, and if the convergence of all such considerations points to one paramount conclusion at the expense of other solutions whose overall probability is less buttressed. The object of this paper is precisely such an attempt to put forward a new explanation for these two mysterious words the French tongue coined under Middle Eastern skies some eight centuries ago.

Our hypothesis and the methodology followed may now be summarized:

a. Both poulain and turcople were originally borrowings.

b. They have an element in common that may be traced to the same fundamental etymon.

c. Onomastics does not seem to have ever been called upon to assist in solving the problem. It is hereby contended that toponymy may shed some light on it.

d. Both lexemes, to varying degrees and at various points in their semantic evolution, functioned as patrials: turcople may well have been a pure patrial before it acquired its specialized military meaning, and poulain did in fact function as an incidental patrial.

e. The plurilingualism reigning in the Latin Kingdom of Jerusalem must have

concealing a soft interior) but as used by present-day first-generation immigrants this term, also originally one of endearment, now often seems to indicate a certain degree of enmity. Other examples of this universal trait could be adduced.

${ }^{4}$ Greimas, loc. cit.

${ }^{5}$ Greimas, op. cit., under turcople, p. 648. The reference is to Chanson d'Aspremont (1188). This literary attestation seems to be the earliest.

${ }^{6}$ T. S. R. Boase, Kingdoms and Strongholds of the Crusaders (London, 1971), p. 67. After mentioning that Suger (1081-1151) writes the word as polini, Boase voices the etymological doubts of James of Vitry (Jacques de Vitry, author of the first attestation of pullani in 1216, see note 1, while polini may be the 1148 version alluded to, but not specified by, Prawer) as well as his own: "James of Vitry, in the following century, writes the word 'pullani' and is not sure whether it meant that compared to the Syrians the crusading settlers were chickens, or that in the early days, since there were 'but few women, as compared with men in the army of Western princes', the settlers fetched brides from the nearest Latin lands of Apulia. The normal use, however derived, was that of Suger." 
been a significant factor favoring the original full or partial borrowing of these terms, and it is suggested that Byzantine Greek was the immediate source of the Old French words, with both Greek Orthodox and Roman Catholic churches acting as a transmission belt.

Before facts are marshalled and organized in support of this new set of hypotheses, a brief review of traditional ones is in order. This is most economically achieved in the following synoptic, tabular form(n.b.: the phrase "No entry" means "no entry under the particular seme under consideration": this is particularly true of poulain. In the case of turcople, the phrase means "no entry at all").

\begin{tabular}{|c|c|c|}
\hline $\begin{array}{l}\text { ETYMOLOGICAL } \\
\text { DICTIONARY OR } \\
\text { OTHER REFERENCE } \\
\text { WORK }\end{array}$ & POULAIN & TURCOPLE \\
\hline Greimas ${ }^{7}$ & No etymon given & $\begin{array}{l}\text { No etymon given, } \\
\text { but glossed as } \\
\text { pàtrial "Turc" } \\
\text { (3rd seme) in } 1260 \\
\text { source (Philippe } \\
\text { Mousket) }\end{array}$ \\
\hline Bloch-Wartburg ${ }^{7}$ & No entry & No entry \\
\hline $\begin{array}{l}\text { Dauzat-Dubois-Mit- } \\
\text { terand }^{7}\end{array}$ & No entry & No entry \\
\hline $\begin{array}{l}\text { Grand Larousse ency- } \\
\text { clopédique }^{7}\end{array}$ & No etymon given & $\begin{array}{l}3 \text { spellings listed: } \\
\text { Turcoples, turcopo- } \\
\text { les, and turcopou- } \\
\text { les, described as } \\
\text { plural only. Etym.: } \\
\text { 'Greek turkopoul } \\
\text { "fils de Turc". }\end{array}$ \\
\hline
\end{tabular}

\footnotetext{
${ }^{7}$ Etymological, Old French and encyclopedic reference works utilized: A. J. Greimas, op. cit.; Oscar Bloch \& Walter von Wartburg, Dictionnaire étymologique de la langue française (Paris, 1964); Albert Dauzat, Jean Dubois \& Henri Mitterand, Nouveau Dictionnaire étymologique et historique (Paris, 1971); Grand Larousse encyclopédique (Paris, 1964); F. Godefroy, Dictionnaire de l'ancien français (Paris, 1881-1902); R. Grandsaignes d'Hauterive, Dictionnaire d'ancien français (Paris, 1947); Jacqueline Picoche, Nouveau dictionnaire étymologique du français (Paris, 1971); E. Gamillscheg, Etymologisches Wörterbuch der französischen Sprache (Heidelberg, 1928); E. Littré, Dictionnaire de la langue française (Paris, 1958 reprint); P. Robert, Dictionnaire alphabétique et analogique de la langue française (Paris, 1962); Hilaire Van Daele, Petit Dictionnaire de l'ancien français (Paris, 1969 reprint).
} 


\begin{tabular}{|c|c|c|}
\hline Godefroy $^{7}$ & $\begin{array}{l}\text { Spelled polain } \\
\text { and poulain, no } \\
\text { etymon given }\end{array}$ & $\begin{array}{l}\text { No etymon given, but } \\
\text { various spellings: } \\
\text { turcople, trucople, } \\
\text { turquople, turchople, } \\
\text { tricople, tracople }\end{array}$ \\
\hline Grandsaignes $^{7}$ & $\begin{array}{l}\text { No etymon given: } \\
\text { "Etym. obscure" }\end{array}$ & No entry \\
\hline Picoche $^{7}$ & No entry & No entry \\
\hline Gamillscheg? & No entry & No entry \\
\hline Littré $^{7}$ & $\begin{array}{l}\text { Arabic fulân, } \\
\text { "un tel" }\end{array}$ & 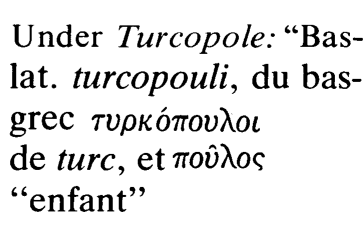 \\
\hline Robert $^{7}$ & No entry & No entry \\
\hline Van Daele ${ }^{7}$ & No entry & $\begin{array}{l}\text { Etym:< "turc+grec } \\
\text { ö } \pi \lambda o s, \text { arme" }\end{array}$ \\
\hline
\end{tabular}

The malaise referred to above is evident from a cursory glance at the table: there is either no etymon given (assuming there is any entry at all) or there is disagreement among authorities as to what the etymon is, or else an honest avowal that the etymology is obscure. Poulain is especially mysterious. As for turcople, it is of interest to note that when authorities venture to ascribe an origin to it, they call upon Greek, preference traditionally going to a */turkopulos/ "son of a Turk." While such an etymology is phonologically and semantically possible, it should be borne in mind that in Greek, forms ending in -poulos (the traditional graphemic rendition in Latin characters, hereinafter utilized) are often used as patronyms but not commonly as patrials. That turcople could be used as patrial as late as 1260 (Mousket reference in Greimas, see also note 21 infra) in the Old French borrowing, with the plain meaning of "Turk," concurrently with its other meanings ("lightly armed Turkish soldier" or plain "Turkish soldier") would seem to show that the "patrialistic" seme is the original one, for it is more likely for the semantic evolution of patrials to proceed from the general to the particular. One may perhaps account for Greek *turcopoulos as patrial by looking at it as a calque from Semitic, in which both Biblical Hebrew and Arabic patrial habits would concur (e.g., Heb. Benei Israel 
"Children of Israel," B'nai Brith "Sons of the Covenant"; Arab. Beni or Banu "sons of..." preceding the name of a tribe). Greek translations of the Bible, from the Septuaginta onward, as well as actual names of Arab tribes dwelling in the Crusader kingdom, would thus provide analogical models for the calque, and the latter may in turn have been borrowed from the Greek by Latin, Old French, and other languages. An ecclesiastical intermediary must be postulated for such a transfer. While seductive, this theory implies a series of borrowings (first semantically, as calque, from Hebrew and/or Arabic by Greek, thence phonologically by Latin, then by French, etc.) which rakes it more problematical. The most economical explanation might be the most probable. And the common root one discerns a priori in poulain and turcople is not satisfactorily accounted for by a *-poulos etymon, for the mere idea of "children," without further qualification, seems insufficient to yield a patrial, while poulain did function as one. But this etymon may have been a contributory factor, and outright rejection would be foolhardy. We are not inclined to look upon it as the decisive one, however.

Proceeding again from the general to the particular, it seems that a clue to the solution of the problem must be sought in the overall linguistic situation in the Latin Kingdom, especially the first one (1099-1188) when the terms first appear. This situation, mutatis mutandis, bears a lot of resemblance with that of the modern state of Israel: it was a mixture of languages, each of the ethnic components of the society speaking its own and often using another for liturgical purposes, with a lingua franca, Old French, more or less uniting the whole. Boase has aptly described the situation: "There was in Jerusalem a babel of tongues and dialects, controlled in official documents by the use of Latin and dominated by a French-speaking court and aristocracy. The jongleurs' poems as they have come down to us, use the same language, but there must have been many problems of communication in this very diverse society." 8 This echoes a celebrated contemporary account by Fulcher of Chartres whose claim to individual or collective polyglot prowess, while significant, must be taken with a grain of salt: "On se sert alternativement des diverses langues. Chaque nation parle une autre langue que la sienne, déjà d'usage commun...",

What were these numerous languages spoken and written in this rather extraordinary ethnic hodgepodge? The ruling minority, that is, the court, the aristocracy and the burghers of "Frankish," and mostly French, origin (never numbering more than 120,000 in the Kingdom of Jerusalem, twice that figure if Antioch and Tripoli be added ${ }^{10}$ ) used Old French, actually at first a variety of

\footnotetext{
${ }^{8}$ T. S. R. Boase, op. cit., p. 39.

${ }^{9}$ Quoted and translated by Jean Richard, Le Royaume latin de Jérusalem (Paris, 1953), p. 30, note 3. Jean Richard refers to Fulcher of Chartres (Foucher de Chartres), Historia Hierosolymitana, Hagenmeyer edition (Heidelberg, 1913), Book III, Chapter XXXVII, no page number supplied.

${ }^{10}$ Statistics according to J. Prawer, op. cit., Vol. I., p. 429.
} 
dialects thereof which must quickly have fused into a koine or lingua francall for common intercourse, one later settlers would adapt to. Such is the perennial way in which colonial languages emanating from societies linguistically as yet not unified have evolved. For instance, in the sixteenth and seventeenth centuries, which are better documented, the French that developed in Québec was a compromise between the dialects of the two main groups of settlers hailing from widely different provinces of the langue d'oil dominion, to wit, Picardy and Saintonge, and this dialectological diversity, together with the time stratum involved and the quasi-total by-passing of Parisian influence, must all be invoked to account for the quirks of Canadian French. A similar process must have taken place in twelfth-century Palestine.

Old Provençal was the official language of the County of Tripoli in what today is Lebanon, as well as the mother-tongue of sizable chunks of the Frankish community in the Kingdom of Jerusalem, for instance in Acre ${ }^{12}$. It, too, must have evolved into a koine of southern dialects. Latin, of course, in addition to liturgical use, was also the written tongue of clerics and official documents as well as some memoirs of the time, e.g., those of William of Tyre (which were, however, duly translated into Old French). It may be surmised that it also served as the spoken koine of Roman clerics of all nations in the Holy Land. State correspondence was also often written in Latin, e.g., that of Richard of Cornwall ${ }^{13}$. The Romance family was also represented, especially in Acre, by the Italian communes (Pisa, Genoa, Venice) which formed tightly knit communities with huge privileges, jealously guarded, while preserving their native dialects. Here too, with time, a compromise tongue of common intircourse may have evolved within the narrow confines of the port of Acre and this early instance of la questione della lingua received a practical solution despite great mutual hostility.

German dialects were spoken by the Teutonic knights and some settlers, especially those who came with the armies of Frederic II. This remarkable figure was an accomplished polyglot whose knowledge of Arabic excited the admiration of even his Moslem enemies but he was certainly exceptional among Germans, who never integrated with the French-speaking Latin majority within

"This use of the term lingua franca here reflects a synonym of koine and must not be confused with another, more specialized though related meaning, i.e., that of the original lingua franca, a pidgin developed by traders and crusaders in the eastèrn Mediterranean during the Middle Ages, based on Provençal and Italian, and designed as a compromise between these Romance tongues and quite dissimilar ones (Arabic, Turkish). On this lingua franca see the thorough study (though limited to nautical vocabulary) by Henry and Renée Kahane, and Andreas Tietze, The Lingua franca in the Levant (Urbana, 1958). The lingua franca pidgin was used until the eighteenth century in the Mediterranean; it bears only a remote relationship to the koine evolved by the Crusaders for their own use on the basis of quite similar Romance dialects.

12“...la majeure partie des bourgeois d'Acre était de souche méridionale." (J. Prawer, op. cit., Vol. II, p. 242.) Several accounts tell of the existence in Acre, in addition to the Italian communes of Venice, Genoa and Pisa, of a Provençal quarter.

${ }_{13}$ Prawer, op. cit., Vol. 11, p. 285. 
the ruling minority, while he was fluent in French.

Arabic was the language of the vanquished majority, the tillers of the soil of Palestine. Turkish was also spoken, as was Hebrew in the Jewish communities of the South which seem to have been bilingual as usual since they also used Arabic. Syriac, a Semitic tongue of the Western Aramaic group, was used by the Christian sect of the Jacobites.

Greek deserves a special mention, both because of its historical importance and of its relevance to the subject matter of this discussion. Greek settlements, such as Caesarea, had been established in Palestine even before the fall of Jerusalem and the dispersal of the Jews (A.D. 70), a dispersal which was never as complete as is commonly believed, for there was not a single generation since the time of Vespasian and Titus when Jews did not continue to inhabit their ancestral land, even if not always the city of Jerusalem. The Roman Empire favored Greek settlement, and Palestine naturally remained in the orbit of the Eastern Roman Empire after its Western counterpart collapsed (476). The official, as well as common, language of Byzantium was of course Greek. Byzantine domination of Palestine lasted for a long time, until the Arab conquest of the seventh century. But this did not spell the automatic disappearance of the Greek tongue: "Arabic slowly replaced Greek as the official language during the seventh century, but it became the local vernacular only some two hundred years later, around the year 800 . It never completely replaced Greek or Aramaic in the North and Hebrew in the South." ${ }^{14}$ Byzantine Greek was thus preserved as a vernacular and of course remained the liturgical language of Greek Orthodox clerics and faithful alike. Prawer says of the Greeks, "Les membres de cette communauté étaient très nombreux dans le pays...." Bilingualism seems to have been prevalent among them: "La langue parlée par ces chrétiens était l'arabe, mais les offices se célébraient en grec." 16 To which one could add that Greeks, just as other national-religious groups in the Crusader Kingdom, had the privilege of using their own tongue in judicial proceedings: "Ces témoins prêtaient serment sur l'Evangile en version arabe, grecque ou syriaque, sur la Bible hébraïque ou sur le Coran, suivant leur appartenance religieuse." 17 By the time the Latin Crusaders appeared under the walls of Jerusalem (1099) the Greek language had been spoken and written in the Holy Land continuously for a millennium.

The Greek Orthodox Church and community may thus have been the donor in the hypothetical linguistic borrowing of poulain and turcople, whose naturalized Old French appearance may well conceal an original Greek etymon whose phonological shape was quite close to the hitherto proposed-poulos (in the case of turcople), though not identical, and which, while bearing a semantic resemblance thereto is nevertheless pretty far removed from it. It is hereby

\footnotetext{
14 Joshua Prawer, The Latin Kingdom of Jerusalem (London, 1972), p. 57.

15 Prawer, Histoire du Royaume..., Vol. I, p. 513.

16 Ibid.

17 Ibid., p. 522.
} 
suggested that the Byzantine Greeks of Palestine, during a period which may well antedate the Crusader conquest, were the probable coiners of a term */turkopolis/ meaning "the city, community or polity of the Turks," a term analogically forged to refer collectively to their Moslem conquerors, of which more infra. This word, once borrowed by the Latins and once it had acquired spoken currency among them as turcople, may have served as an analogical model for the coining of poulain, assuming the latter was not also borrowed directly from the Greek, a possibility which is not negligible. As previously stated, the possible agent for the transmission of these borrowings was the Latin Church, whence the terms may have gained currency among the knightly class and finally the Frankish bourgeois. Semantic changes undergone by the borrowed words, as well as the linguistic plausibility of the entire process, are hereafter examined.

It is probable that *turcopolis preceded poulain, which makes sense since the "Turks" (a term encompassing actual Turks and also Arabs, at any rate Moslems, sometimes also called Saracens) were present and dominant in Palestine for four centuries before the Latins showed up in force. We shall accordingly first focus on that possibility. It can be shown that attested analogical models, fairly numerous, had been in existence in Hellenophonous toponymy in and out of Palestine for a long time, based on -polis "city, polity, etc.," and that the regular outcome of such Greek toponyms when borrowed or phonologically adapted by Old French is a French place-name ending in -Vple, where $\mathrm{V}$ represents various vowels but in practice mostly /o/, thus paving the way for acceptance of turcople $<* /$ turkópolis/. This historical phonological process is but one particular case of a more general rule which could be succinctly formulated as follows:

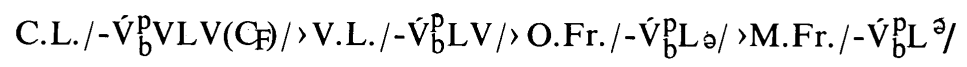

which may be read, amplified and understood thus:

"Classical Latin words, including borrowings, ending in a stressed vowel followed by a voiced or unvoiced bilabial stop, followed in turn by an unstressed vowel plus liquid plus another unstressed vowel followed by a final consonant (usually a case ending, mostly accusative -M) which was already on its way to being dropped, regularly yielded in Vulgar Latin the same combination minus the post-tonic vowel, which dropped out by syncope, and the final consonant; and in Old French, in the oblique case, a similar combination but with the final vowel, no matter what its nature, reduced to a uniform $/ a /$ used as a supporting vowel to the preceding unwieldy consonant sequence in final syllable, the modern French outcome remaining almost the same (except for the phonetic nature of liquid $/ 1 /$ ) in the pronunciation of southern France where final shwa is heard distinctly while in the north it is barely audible, being enunciated, as it were, in appogiatura fashion." 
Examples are numerous: DIABOLU(M) > diable (originally a Greek borrowing); DISCIPULU(M) > disciple; TABULA(M) > table; COPULA(M) > couple; MOBILE(M)'meuble; Latin adjectival suffixes-ABILIS,-IBILIS,-OBILIS yielding, through the accusative, later oblique form in -BILE(M), French adjectival suffixes -able, -ible, -oble, etc. ${ }^{1 *}$ Greek ending /-V́ + polis/, where $\mathrm{V}$ could be actualized by any stressed vowel but usually was by /ó/ from the combination form, was destined to be toponomastically prolific in French, via a Latin adaptation.

On the semantic front, the Greek root polis, polit-, meant not only "city" in the modern narrower sense of the word, but also "city-state, state, organized society or group"; also, if used metaphorically, any collection of select and elect human beings (as in Saint Augustine's Latin equivalent Civitas Dei). It has survived in its free-morpheme Greek form in French philosophical parlance to this day, though still usually printed in italics. Its derived forms are at the origin of various lexemes common to many Western tongues, e.g., Eng. politics, polity, policy, police, etc., whose basic semantic referent is the same, that of the organized group of humans. As a toponymic morpheme-suffix, -polis is found not only in all former Byzantine possessions but also throughout the entire former Roman Empire, and not only where Greek coastal colonies existed. This would indicate that the toponymic suffix was well known and used even by Latin speakers for new toponymic creations, a process bequeathed to the Romance languages and extending well into the Middle Ages. It was then picked up by geographers, cartographers and historians from the Renaissance on, and by writers of fiction to our own day. ${ }^{19}$ As an actual or generic place-naming device it has continued in the New World (e.g., Minneapolis, Indianapolis, Annapolis, the lexeme metropolis, in the United States; Petropolis, Therezopolis, Florianopolis in Brazil, etc.). It is indeed well entrenched in the Western mind.

Consideration of some ancient and medieval examples of this linguistictoponymic evolution will illustrate the multiplicity and weight of analogical models. Examples are grouped by broad areas (West, East and Middle East):

I) In the former Western Roman Empire:

NEAPOLIS "new city"> It. Napoli, adapted by French as Naples (final $s$ is

\footnotetext{
${ }^{18}$ It should be noted for the sake of completeness that in some cases the Old French outcome of Latin liquid /1/ is the other liquid of the $\mathrm{O}$. Fr. system, $/ \mathrm{r} /$. This process may sometimes be analogical rather than truly etymological. Two forms may even coexist for a while, e.g., sinople and sinopre (Greimas, op. cit., who derives it from the Greek sinopis). Since the toponymic origin of this name of a color is undeniable (see text infra and note 30) one is much tempted to postulate a reconstructed etymon, whether real or clerically imagined, *SINOPOLIS, instead of Greimas's sinopis which cannot phonetically yield either liquid directly.

${ }^{19}$ Even children are expected to identify -polis as a morpheme-suffix of toponymic creation. For instance, a French science-fiction novel of the late thirties, by $O$. Hanstein, depicting a super-technological new city built near a mountain rich in pitchblende (a radium ore), is entitled Radiopolis. It appeared in the child-oriented Collection “Aventures et Voyages" (Paris, 1939, published by Fernand Nathan). In American comic strips, the Superman series has the hero, Clark Kent, alias Superman, working as a newspaperman in Metropolis, which thus switches from a generic lexeme to a specific American fictional toponym for children's consumption.
} 
coincidentally paragogic rather than truly etymological, due to scribal habits). NEAPOLIS, in Provençal territory, > La Napoule (near Nice, itself an ancient Greek colony). MONOPOLIS "only, unique city" > It. Monopoli (Puglie). ANTIPOLIS "city facing another" (in this case Nice, across the bay)> Antibes. But a 1235 attestation ${ }^{20}$ has it as Antibol, and the various steps are easily reconstructed: ANTÍPOLIS > *Antípol > Antíbol >*Antible > Antıbes (final $s$ again paragogic). The dropping of $/ 1 /$ is unusual.

GRATIANOPOLIS > Grenoble in France (in the Franco-Provençal dialectological region). As with Antibes, this form shows that in France the etymological unvoiced consonant $/ \mathrm{p} /$ may become the voiced $/ \mathrm{b} /$. Documentary evidence suggests that there must even have been some degree of free variation between $/ \mathrm{p} /$ and $/ \mathrm{b} /$ before each form settled down to its "permanent" shape, causing scribes to be unsure of which phoneme they heard in an unstressed final syllable environment. 21 The evolution of Grenoble is particularly interesting and relevant to our subject: it had first been known to GalloRomans as Cularonensis (perhaps from Gaulish cularo "cucumber")22. In the fourth century A.D. Emperor Gratian founded a bishopric there and the city asked to take on the name of the emperor. A fourth-century attestation thus lists it as EPISCOPUS GRATIANOPOLITANUS, derived from GRATIANOPOLIS "city of Gratian," 23 with the usual Greek combination form in -o-and the derived patrial form, Latinized into-POLITANUS "he who belongs to such and such a city, group, or polity; a citizen or subject thereof." This was to yield the learned French patrial suffix -politain which became widespread (e.g., Napolitain, Tripolitain) as a pure patrial or, in at least one case, as a non-patrial adjective of patrialistic origin, Fr. métropolitain (also used as a noun referring to a Catholic archbishop). The semantics of métropolitain in all its uses involves the relationship of a "mother city" or even a "mother region or country" (cf. the various meanings of French métropole) to its colonies, subdivisions or dependencies." That the modern patrial for Grenoble is Grenoblois and not the expected *Grenopolitain shows

\footnotetext{
20 Albert Dauzat and Charles Rostaing, Dictionnaire des noms de lieux de France (Paris, 1963), p. 21.

${ }^{21}$ Thus the city of Constantinople, spelled in French with a $p$ for several centuries, was quite often spelled with a $b$ during the Middle Ages, as in the following two interesting examples from chroniclers of the Crusades where the spelling in $b$ is made to rhyme with Turcople, spelled with a $p: 1$ ) "Si s'atorna, comme proissies De soucorre Constantinoble Qu'asise avoient li Turcople Et li Blacois et li Coumains.” (Ph. Mousk., Chron., 29521, Reiff),2) "Dont il avint que le Tricople Vosist estre en Constantinoble" (Guill. Machault, Prise d'Alex., 6166, Mas Latrie). These quotations, taken from F. Godefroy, op. cit., under entry "Turcople", in addition to showing that in final unstressed syllable position the scribes perceived $[\mathrm{p}]$ and $[\mathrm{b}]+/ 1 /$ as two allophones of the same phoneme rather than as the two separate phonemes /p/ and / b/ which the Old French system did possess and which were duly registered by separate graphemes $p$ and $b$, unless the writers were content with plain assonance, also prove that Turcople was used as a pure patrial "Turk" in addition to its more specialized military meaning, as suggested supra. ${ }^{22}$ Dauzat \& Rostaing, op. cit., p. 332, under Grenoble. ${ }^{23}$ Ibid.

"4 See definitions of both métropole and métropolitain in Claude \& Paul Augé, Nouveau Petit Larousse illustré (Paris, 1956).
} 
that a repatrialization took place after the phonetic evolution of the toponym into Grenoble, with the suffix -ois<-É(N) S (EM) replacing the former; this process took place, presumably, because of the sheer bulkiness of the former patrial.

Interestingly, Antibes has two patrials: Antipolitain and Antibois, a living illustration of the existence of two competing forms, neither of which ever won out. Though examples on French soil are not that numerous one may still state that patrials in the French language relating to foreign place-names resisted phonological erosion better than home-grown ones, probably because of much lower frequency of use. A further illustration of this proposition is found in an interesting phonetic doublet consisting of two isotoponyms (strictly, and etymologically speaking, they are rather two "isopatrials"): one member of the doublet, the learned one, is the stillborn *Grenopolitain (attested in its Vulgar Latin stage) and the second, or popular, member is a true toponym, very much alive as a place-name though originally a patrial: Grésivaudan, also spelled Graisivaudan. According to Dauzat this form derives from the same etymon GRATIANOPOLITANUM as the patrial of GRATIANOPOLIS. ${ }^{25}$ It is not a city, but the name given to a portion of the Isère valley, starting at and proceeding northeast of Grenoble. Such intimate geographical connection suggests a former toponomastic adjectival use of the patrial as part of a longer toponym, such as *VALLE(M) GRATIANOPOLITANU(M) meaning simply the "vale of Grenoble," which may have gone on by ellipsis to its present form (a rather common process in French toponymy). ${ }^{26}$ This form represents a perfect popular phonological outcome, in Franco-Provençal, of the Latin patrial; the

\footnotetext{
${ }^{25}$ Albert Dauzat, La toponymie française(Paris, 1960),p.59, note 4. The author considers the suffix -ITANUS as a patrial one, of course, and states that it is even pre-Latin in origin and quite alive in Vulgar and Medieval Latin (e.g., HIEROSOLOMYTANU(M)). -BALITANUM and -POLITANUM are described as yielding the same French outcome in -vaudan (GABALITANUM>Gévaudan, another patrial that became a toponym designating a mountain region in southern France, near Mende, and whose inhabitants are still called Gabalitains). This is phonologically quite plausible and provides an indirect proof of the validity of the -POLITANU(M)>-vaudan evolution. It would also seem to show that patrial suffix -ITANUM was blended with borrowed Greek polis to yield Vulgar Latin-POLITANUM, a process facilitated by the Greek derived forms with / $t$ ( polites, politeia) at least as early as the fourth century. That GABALITANUM is a full patrial in its own right, not built on any original *POLIT- root, seems further confirmed by Dauzat and Rostaing,op. cit., p. 321, under entry "Givardon.” The village of Givaudins shows the following attestations: Javaddam (10th cent.); Jevaldaniacum (1086); Gevaldan (1137); Jevaudens (1226). With due regard to scribal habits and vagaries this sequence basically confirms our reconstruction sequence infra (-POLITANU(M) -vaudan).

${ }^{26}$ Classical Latin VALLE(M) was feminine but became masculine in Gaul, yielding Old and Modern French val, already attested as such in the Chanson de Roland, ca. 1080 (Greimas, op. cit., p. 654). As for toponymic ellipsis on French soil, north and south, it is so common as to constitute a classic situation (e.g., the thousands of place-names ending in $-y$ in the north, in $-a c$ in the south, both reflexes of the patrial adjectival ending - ACUM used in connection with Gallo-Roman rural domains, the nuclei of villages; for instance, the prolific combination FUNDUM + patrial adjective, later ellipticized into the second element only. e.g., FUNDUM AURELIACUM > Orly in the north, Aurillac in the south. See Dauzat's Toponymie française, passim.
} 
evolution of the suffix may be reconstructed as follows in one suggested sequence (only graphemic transcription used): -PÒLITÁNU(M) > *pòlidán > *boldán > *voldán > *valdán > -vaudan.

Any variants in the steps of this reconstruction (e.g., an intermediate step bàlidán<-BALITANUM, an attested patrial ending, with a more remote possibility of its being a reflex of -POLITANU(M), though this is not suggested by Dauzat and Rostaing, see note 25 ) sequence would in no wise alter the important toponomastic fact that attested Latin -POLITANU(M) yields Franco-Provençal -vaudan, in actual toponymic use. We shall have occasion to remind the reader of this historical phonological evolution when examining the French-speaking Crusader Middle East.

For the sake of completeness one should mention that in addition to the patrial suffix -politain French also has a competing simpler form -polite (e.g., cosmopolite, métropolite) theoretically resulting from a shift of stress in the etymon. ${ }^{27}$ By way of contrast, English has only retained the fuller form in -politan. ${ }^{28}$ French words ending in -polite are quite rare and are semantically more remotely toponymic, though the connection remains, than those ending in -politain. ${ }^{29}$

We would end this Western survey by noting that outside of toponyms French words ending in -ople are quite rare. One source lists only two: ${ }^{30} 1$ ) sinople, the name of a color (red in the twelfth century, inexplicably turning

\footnotetext{
${ }^{27}$-politain<-POLITÁNU(M) and -polite<*-POLÍTANU(M) but the late date of attestations of the very rare instances of French words ending in -polite (cosmopolite, 1560; métropolite, 1842, according to Dauzat-DuboisMitterand, op. cit.),plus the fact that-polite is never used as a true patrial suffix in French, all militate against a true phonetic doublet during the medieval development of the language (a regular outcome for the popular second member might have been * métropolain if a true reflex of METROPOLITANU(M) and * métrople if a reflex of METROPOLIS) and in favor of a late, learned, analogical creation. Models such as hoplite might have played a role, as well as the fact that -ite (as in Bible patrials Amalécite, Jébusite, etc., or more recent Annamite), as opposed to -polite, is in fact used as a patrial in French and the semantic and formal connection would not be lost on the coiners; or the latter might quite simply have used the model of Greek root polit-which they knew was derived from polis. As usual in the history of doublets, whether phonetically authentic ones or analogical ones, there is a semantic specialization of each member: métropolite refers to a Greek Orthodox Church dignitary, in contradistinction to his Roman Catholic colleague, but this seems to be a nineteenth-century development.

${ }^{28}$ English metropolitan is so deeply internalized in the American culture that even here the -politan element is perceived popularly as a separate morpheme which can be re-used in other combinations. If this were not so one could not explain the success of such coinages as Kuklapolitans, popularized as a sort of patrial some years ago on an American television children's program (Kukla, Fran and Ollie). The analogical model may however have been the patrials for Minneapolis, Indianapolis, Annapolis, Thermopolis (Wyoming), etc., but even this would not detract from the exemplarity of metropolis and metropolitan. With the neologism megalopolis now well etablished, can a patrial *megalopolitan be far behind? [For Megalopolis as a proper noun, $c f$. the founding of a city so named by Epaminondas, 369 B.C., in the Peloponnesus. Ed. note.]

${ }^{29}$ The two words given above are the only ones listed in the corpus of the Dictionnaire inverse de la langue française (The Hague, 1965), a broad computerized survey by Alphonse Juilland (p. 387).

${ }^{30}$ Ibid., p.220. The fact that Juilland has not included place-names in his corpus (though some patrials appear, as
} 
green in the fourteenth), used in heraldry. Ironically, it is also of toponymic origin (from the ancient city of Sinop in Turkey) and one may wonder whether the intrusion of a non-etymological / / does not show an analogical Old French creation on the model of the names of cities in -ople discussed above (cf. note 18); 2) just as toponymic in origin, the only other word mentioned in Juilland's list: andrinople, the name of a red-colored cloth originating in the city of Andrinople, also in Turkey (Edirne in Turkish, Adrianople in English, named after Emperor Hadrian); the French patrial is Andrinopolitain. It might be added that Andrinople was part of the misguided Crusader Kingdom of Constantinople, a fleeting heir to the Byzantines, as was Sinop. As for French lexical items ending in -oble, there are only three in the lexicon (noble, ignoble, vignoble $^{31}$ and toponymy accounts for all others, either today or as former stages in the phonological evolution (e.g., spelling Constantinoble in Old French).

II) In the former Byzantine Empire, exclusive of Middle Eastern Crusader establishments:

Toponyms in -pol characterize present-day Russian territory, e.g., Sevastopol SEBASTOPOLIS, Simferopol, Marioupol, etc. concentrated in and around Crimea (ancient Tauris), a focus of Greek settlement since ancient times. Because of their imperial, Christian connotations, these names refer to Byzantine rather than ancient Greek colonies. Curiously, the name of the former inhabitants of the region, the ancient Scyths, is also found as part of a placename of the Holy Land, Scythopolis (ancient Israelite Beisan in Western transcription, a name kept by the Arabs, adopted by the Franks, and restored to its original Hebrew form / bejtšan/ today) in classical, New Testament times, when it became the chief city of the Decapolis (of which more below). Bulgaria has both -polis and -poli (e.g., Nicopolis, Philippopoli. In Turkey, -polis yields -bolu (e.g., Gallipoli "city of Celts" $>$ Gelibolu), or -bul as in the greatly eroded Gk. Konstantinopolis $>$ Turk. Istanbul or Stanbul. Greece, of course, has many toponyms in -polis, ancient and modern: a) direct forms: Amtipolis, Eleftheroupolis, Hrissoupolis, Paleopolis, Megalopolis, etc.; b) derived forms, e.g., Tripolitsa<TRIPOLIS "three cities", 32 the latter pattern found again in Libya as the name of a city, Tripoli, and that of the surrounding region, in a patrially derived Latin form: TRIPOLITANIA, as well as in Lebanon, again as

\footnotetext{
adjectives, not as nouns) is an impoverishment of the results of his survey. Surely the currency of sinople or andrinople as names of color or cloth is not as wide as the use of Andrinople or Constantinople (even though the place is known today as Istanboul) in the language, if only in connection with history and geography. The systematic avoidance of onomastic data (even Paris is not listed!) in a lexicological inventory of such magnitude and thoroughness is to be deplored. Indeed, an inverse Gazetteer would be a most useful tool for onomastic research.

${ }^{31}$ Ibid., p.211. The same remarks as above apply here: surely the frequency of use, both spoken and written, in the French language of an important city like Grenoble compares quite favorably with that of, e.g., noble, or even vignoble.

${ }^{32}$ Encyclopaedia Britannica, 1961 Edition, Vol. 22, under entries TRIPOLI. TRIPOLITANIA AND TRIPOLITSA
} 
Tripoli, a perfect isotoponym of the other Tripoli, one thousand miles to the west. Tripoli, a Western outcome of TRIPOLIS, is not the Arabic, indigenous version of the name. Arabic adaptations of -polis regularly yield -bulus; Tripoli of Libya and Tripoli of Lebanon are both transcribed locally as Tarabulus. This Middle Eastern incursion brings us to the area of our paramount concern.

III) The Middle East

Toponyms ending in -polis (whether actual Greek creations or adaptations of alien place-names) abounded in Hellenistic times: not only do we find Eleutheropolis, Heliopolis, Persepolis, Ornithopolis, etc., as names of single cities but proof of the potential semantic enlargement of the root, already evidenced by the several Tripolis originating in three amalgamated cities, ${ }^{33}$ is further demonstrated by the Decapolis "ten cities," too widely separated to have been merged into a single urban conglomeration and thus designating an entire region englobing ten cities (among them Caesarea Philippi, later Paneas , today's Baniyas [ the god Pan]; Scythopolis, chief city of the Decapolis, etc.) united in a defensive league. It may thus be retained, on the semantic plane, that here too -polis could be extended in terms of both geographical space and population, as was the case of Grésivaudan in France. We therefore submit that neither semantically nor phonologically nor onomastically is there any objection to a possible derivation of Turcople $<*$ /turkopolis/, it being understood that the latter etymon might originally have referred to an area as small as the Moslem quarter of a city or as large as an entire, broad regional community, or even all of "Moslemdom": we may never know, but that is not the most important point. What matters is how such a collective designation, a toponym, came also to refer to individuals belonging to it, in other words, the patrialization of a toponym without derivation or formal change. Now that, too, is not an unusual phenomenon in onomastics, ${ }^{34}$ even though it is not common; such a semantic patrialistic individualization as the starting point of potential other semantic

Onomastic osmosis exists between city and broad region since Tripolitania is also called Tripoli, the name of a city. 33 There was also at least one Tetrapolis "four cities," in ancient Attica (see Zacharie Mayani, The Etruscans begin to speak [London, 1962] pp. 79-80). On the phonological plane, one should not leave the subject of Tripoli without pointing out that in the Provençal of the County of Tripoli, the latter toponym was called Tripol, a regular outcome in that dialect (cf. Antibol for Antibes, La Napoule for Naples): "Et enamoret se de la comtessa de Tripol. .." (Jaufre Rudel) "Mas a Tripol m'ado. . ." (Peire Vidal).Examples found in F. Hamlin, P.T. Ricketts and J. Hathaway, Introduction à l'élude de l'ancien provençal (Geneva, 1967), pp. 87 and 150 respectively. Also, Lesbos was known in Antiquity as Pentapolis, a name that also appears in Libya ("five cities").

${ }^{34}$ No medieval analogical examples spring to mind but the pattern is clear from the Renaissance onwards, e.g., Suisse, a single form which designates a country, a patrial, both noun and adjective, both masculine and feminine, plus (last, but not least) a special type of mercenary soldier (an analogy with medieval Turcople) and later a beadle. (In the feminine patrial, Suissesse is an accepted substitute in French but seems awkward to many French speakers because of the abundance of sibilants.) There is abundant reference in seventeenth-century literature to the fact that domestic male servants in Parisian aristocratic households were often called not by their first name but either by their patrial (e.g., Proven same time (e.g., Champagne; both examples culled from Molière's play Les Précieuses ridicules, Scene XI). 
changes is not restricted to France or to the past: It is alive in America today. ${ }^{35}$

The universal semantic-toponymic pattern "new place, new city, new settlement, etc.," 36 is operative with -polis in the Middle East as elsewhere. The same prolific Greek etymon NEAPOLIS here yields Arab. Nablus, Gallicized by the Franks into Naples, ${ }^{37}$ an isotoponym of Fr. Naples (Italy), Prov. La Napoule, etc. The modern French form is closer to the Arabic, however: Naplouse.

Cyprus provides a direct proof that polis as a free morpheme was still sufficiently alive as a place-naming device among thirteenth-century French Crusaders to be actually used as such for a new toponymic creation on the island. ${ }^{38}$

In the Holy Land itself there would seem to be some actual proof of the plausibility of the sequence of events evoked above, in the case of a Crusader toponymic creation, or rather adaptation. Betenoble. Any temptation to see in it a Crusader popular etymology or downright coinage "noble steed" is quickly disposed of by considering that in the twelfth century Fr. bete « V.L. BESTA r C.L. BESTIA was still pronounced /bestə/ and spelled beste, a fact which would suffice to reject such a version even if independent evidence were not available. But the full story of this place-name is rather well attested and would seem to show again that Greek, and particularly -polis, was still consciously used as a place-naming model as late as that period and beyond (cf. Cypriot Polis), a feat which was only possible through clerical channels in a polyglot environment, which in the Holy Land was Arabic-Greek-Latin-French. An existing Arabic toponym Beit-Nuba served as model and was Hellenized as BETENOPOLIS and Gallicized as.Betenoble when the Crusaders undertook to build a castle in the vicinity, to be known as Château-Arnauld. ${ }^{39}$ The Semitic root is well

\footnotetext{
${ }^{35}$ In many Western stories and films cowboy characters are nicknamed after their home states without any further qualification: Arizona, Nevada, Montana, etc. The author has personally observed similar anthroponymic patterns while serving with the United States Army.

${ }^{36}$ This is especially evident in Romance. Germanic and Semitic toponymy in connection with the building of new fortressess, usually nuclei of later villages and towns. See H. Diament, The toponomastic reflexes of Castellum and Castrum, a comparative pan-Romanic study (Heidelberg, 1972), passim.

${ }^{37}$ This spelling found in Joinville: “Celi soir appela li roys sa gent, et leur dist...que il iroit prendre une cité des Sarrazins que on apele Naples, laquel cité les anciennes escriptures appelent Samarie." (Histoire de Saint Louis, in Historiens et Chroniqueurs du Moyen Age, Bibliothèque de la Pléiade [Paris, 1952]. p. 326) Naples identified as Naplouse, ibid., p. 1482.

${ }^{38}$ Polis (ancient Marion, Arsinoe) is located near the northern coast of Cyprus, almost at the westernmost tip of the island, near the "Baths of Aphrodite." It is an elliptical form of "Polis tis Khrysokhou" but this is a latter-day administrative appellation as Polis has become a sub-district capital. Prof. John Tsiknopoulos specifically states that the Roman and Byzantine name, Arsinoe (after the sister of Ptolemy Philadelphus) was changed to plain Polis "city" by the Crusader Lusignan dynasty (1192-1489). See Aphrodite's realm, an illustrated Guide and Handbook to Cyprus, edited by Robin Parker (Nicosia, 1963, revised edition), p. 154, under the signature of Prof. John Tsiknopoulos.

${ }^{39}$ Prawer, Histoire..., Vol. I, p. 328.
} 
preserved but the addition and blending of -polis is significant. The building of the fortress and the names involved are dated precisely as 1132 , one and one-half generations after the 1099 conquest. This is far too short a time for the regular phonological erosion process outlined above, i.e., BETENOPOLIS $>$ Betenoble, to have taken place even assuming BETENOPOLIS to have existed in Greekspeaking circles to refer to Beit-Nuba from the very beginning of Christian conquest, which is not proven. If this regular historical process of sound change had taken place it would be truly remarkable how quickly the Greek etymon was naturalized into the French-sounding place-name Betenoble (an intermediate * Betenople being necessary in theory though in practice one may discount it on grounds of scribal imprecision described supra). The contemporary situation appears to suggest that Betenopolis and Betenoble were coined simultaneously, the former for learned and the latter for popular use, and that the required several generations were not given a chance to let French Historical Phonology do its work, assuming that such a regular phonological change was not an anachronism after 1132 . While not entirely impossible, it would be improbable to suggest that Ar. Beit-Nuba yielded Old French Betenoble directly, but if such a thing did happen one would have to conclude that Betenopolis was coined as a clerical backformation in accordance with a pattern of conscious association of ideas, an awareness of analogical models of an otherwise quite unconscious historical phonological sequence. The proposition works both ways: if, as is likely, Betenopolis is a Crusader clerical coining to transcribe Beit-Nuba (since the Greek-type form is not attested in ancient times ${ }^{40}$ ) the mental equation " $\mathrm{Gr}$. BETENOPOLIS = Fr. Betenoble" seems to be synchronic rather than diachronic in this case. Such flagrant clerical consciousness of the correspondence involved lends additional credence to a Greek clerical * Turcopolis as phonological ancestor of turcople, and it has been seen that semantics as a pure patrial, inter alia, is actually attested (note 21). Last, it will be remembered that turcopoles and turcopoules spellings are also attested: this seems to bolster the probability of a *Turcopolis etymon on two possible grounds: a) either by providing an attested intermediate step (or even two) in the Old French phonological transition from *Turcopolis to turcople(s), or, b) if the text of the attestation be Provençal rather than French, by showing that such spellings would represent quite regular outcomes in Langue d'oc (cf. Tripol for Tripoli, a Provençal-speaking entity, which Old French recorded as Tripe; or La Napoule vs. Naples in O.Fr. from the same etymon NEAPOLIS). ${ }^{+1}$

\footnotetext{
${ }^{40} \mathrm{Ibid}$. Prawer specifically states: "(Betenopolis ou Bétenoble pour les croisés)..." and does not suggest that Betenopolis was known as such to ancient or Byzantine Greeks before the arrival of the Crusaders. One may thus assume that its absolute earliest coining was Byzantine and most probably an actual Crusader creation. Even if it is the former, documents still show at least a Frankish borrowing and adaptation akin to our postulated *TURCOPOLIS > Turcople.

${ }^{41}$ Cf. "...li cuens de Tripe..." in Robert de Clari, La conquête de Constantinople (ca. 1216), in Historiens et Chroniqueurs..., p. 30. Tripe is identified with Tripoli on p. 1491, ibid. One would have expected *Triple (cf. Antibol $>$ Fr. Antibes) but in this case the dropping of /1/ may be explained by the lexical existence of trible, first
} 
How may the example of turcople help explain the appearance in Crusader French of poulain? There is no doubt that Poulain, in spite of the affective semantic evolution it underwent referred first and foremost to a noun of nationality, a sort of patrial restricted to the Frankish natives of the Latin Kingdom, at first only half-breeds and then all Palestine-born Franks. Some further evidence of its "patriality" if provided by the fact that the form found its way into toponymy: Passe-Poulain was the Crusader name given to the coastal narrow passage separating the Kingdom of Jerusalem's Seigneurie royale d'Acre from its neighbor fief, the Seigneurie de Scandalion, in the early days of settlement. ${ }^{42}$

Traditional explanations are weak: 1) The name Poulain is supposed to be derived from APULIA, the ancient name of a province that was to supply muchneeded brides to the Crusaders (the Italian province of Puglia or Le Puglie, hence Fr. Pouille[s] Such an etymology would perhaps be better defended by considering that Crusaders would often gather and embark for Palestine in southern Italian Adriatic ports, that the province was part of the Norman Kingdom of the Two Sicilies (whose official language was also French) and that at least one toponymic instance on French soil might have served as a further model (Champagne pouilleuse) for translating the Italian patrial Pugliese as * Pouilleux. This, then, is the patrial one would expect in French if APULIA were the etymon, and not Poulain, for which there is neither Italian nor French obvious model. Though Italian Pugliese derived from Puglie` APULIAE does not carry any derogatory connotations, it would have been different with Fr. pouilleux ("lousy") as an incipient patrial whose intrinsic meaning was obvious when applied by and to people of French speech, ${ }^{43}$ a meaning quite incompatible with the dignity of children of knights, which probably explains why it aborted. But if Poulain is not <APULIA, can this explanation be saved by deriving it from

attested in 1190 as treble (TRIPLUM, later triple. Triple for Tripoli is, however, attested some 30 years before de Clari (see Eracles, in Recueil des Historiensdes Croisades [Paris, 1844], Vol. I, chapters XIII and XIV, p. 625).

${ }^{42}$ Passe-Poulain corresponds to modern Hebrew Rosh-Haniqra (Arab. Ras-al-Naqura), a cape and border post at the Israel-Lebanon frontier. The Crusaders also called it "L'Echelle de Tyr" (Prawer, Histoire..., Vol. I, p. 220). It has served as a natural border from time immemorial and as a limit to a variety of fiefs and loyalties during the 200 years of the Crusaders' presence. Semantically and toponymically, Passe-Poulain stands in contrast with PasPaïen (also spelled Passe-Paien) "Heathen Pass," the frontier between the Kingdom of Jerusalem and the County of Tripoli (ibid., p. 665), further north. No doubt no slur was intended against the Christian, Provençal-speaking county but the pass must have been frequently used as a Moslem invasion route to acquire such a name. Passe-Poulain is an example of the somewhat rare process whereby a patrial of indirect toponymic origin according to our theory (and certainly not of direct such origin) generated a toponym directly whereas the reverse is the rule, patrials stemming from toponyms in direct and usually recognizable fashion though exceptions may occur (cf. Eng. patrial Dutch not directly linked to toponym Holland).

${ }^{43}$ Pouilleux is first attested in the twelfth century as poillos "plein de poux" and in 1226 with the meaning "De mauvaise qualité, stérile," in various archives départementales (Greimas, op. cit., under poil, p. 498) which illustrate its toponymic use for poor soils already referred to in Champagne pouilleuse. As for APULIA, its Classical patrials were APULICUS and APULUS. 
a Latin patrial *ÀPULIÁNU(M)? Historical phonology militatés against it since the total disappearance of the initial syllable of the etymon, which bore a secondary stress, is unlikely if a regular development took place, in which case one might expect a form like * Auliain or *Oillain or even *Olain. But It. Puglia and Puglie do show that in fact APÚLIA > PÚLIA and this explanation of Poulain might still be saved but only by invoking yet another repatrialization in the face of a twin set of available patrials, learned *(A)pulien and popular Pouilleux, a repatrialization which may be a hybrid of the two forms, the root of Pouilleux (either because of its intrinsic negative connotations or because it was already the French equivalent of It. patrial Pugliese) being stripped of -os(-eux) and adding -ien or -ein. This might also explain the attested spelling polein, alternating with polain. While more extraordinary hybrids are known to have occurred in the History of French (e.g., brûler < Old Germ. brennjan + V.L. USTULARE) such an explanation remains laborious and not very likely;2) It is more tempting, as many do, to see in Poulain an original term of endearment for children of knightly horsemen, since the word ostensibly means "colt" 44 but then one may wonder why the term never arose in France itself, where these knights presumably also fathered children, but only in Oultremer; 45 and also why Poulain came to have a derogatory meaning, a fact which is also incompatible with such a knightly origin, given the later attested identification

"V.L. *PULLANU(M)<C.L. PULlAMEN, which in Old French meant the young of any animal (Greimas, op. cit., under polain, p. 500) before semantically specializing as "colt." It should be noted that O. Fr. polain already had five separate meanings, not counting derived forms, and that one of these semes was already a patrial "Polish" attested in 1360 in Froissart. While this patrial must have existed long before its first attestation, it would be far-fetched to see in this a direct model for Palestinian French poulain. Nevertheless the mere fact that it did exist as a patrial is significant. Greimas gives no etymology but the sequence was probably the "irregular" Lat. POLONIU(M) $>$ POLANIUM $>$ polain instead of the expected * polon. This seme had its form later replaced by Polonais, yet another repatrialization, unless here again we have a case of a learned-popular doublet with the learned word winning out (though Polonais and Poulain could not have the exact same etymon, since the suffixes are of different origin, -É(N)SE(M) and -ÁNU(M), and the roots, one Slavic and the other Greek or Latin, are the same only through phonetic coincidence; the two patrials would then be functionally, if not exactly etymologically, a doublet). One cannot leave the subject of the pol- root meaning "colt" without remembering that, in the twilight of the Middle Ages, Erasmus used the Latin word PULLUS onomastically with the meaning of "colt" as a "translation" of the name of his friend Colet, according to his biographer Preserved Smith (Erasmus, New York, 1962, p. 70, note 3) who furthermore mentions another Englishman rendered by Erasmus as POLUS whom Smith identifies as Thomas More's father-in-law, John Colt, on the basis that "The Greek word Polos means 'colt'..." (ibid., p. 81). If correct, this etymology would be one more factor favoring a Greek etymon for both poulain and turcople, explaining the former directly (including why the term did not arise in France) and suggesting a "Turkish colt" semantic mirror image ( *TURCOPOLOS) for the other half-breed group (see note 55 infra). Together with poulos, polos may at least have acted as an incipient semantic and phonetic contributory factor, but the evidence, though intriguing, does not seem sufficiently overwhelming to prefer this version of the genesis of our Crusader lexemes to that suggested by the numerous toponymic analogical models in -polis or its patrial, which is the crux of our hypothesis.

45"Overseas," the standard designation for the Holy Land by French Crusaders (though for the Poulains it was, 
of Poulains as lower-class Franks. ${ }^{46}$

Our own proposed solution will once again call upon the extreme polyglottism of the Latin Kingdom of Jerusalem and other Crusader establishments, and on their intellectual elite, such as it was then and there: the churchmen. ${ }^{47}$ We are told by J. Prawer that in the principality of Antioch and in the county of Tripoli, for instance, “...le grec et l'arabe s'y parlaient couramment

naturally, Europe). In its fundamental meaning of "young animal" poulain is attested from the beginning of the twelfth century (see note 44) but no significance should be attached to the fact that its first attestation in Old French coincides with the coming of age of the first generation of Palestinian Poulains, as the date of attestations is an aleatory matter, and besides this one stems from the mother country.

${ }^{46}$ Even knightly poulains could be the object of ridicule by aristocratic mainlanders, e.g., "On appelle les paisans dou pais poulains; dont messires Pierres d'Avallon, qui demeuroit a Sur, oy dire que on m'appeloit poulain pour ce que j'avoie consellié au roy sa demouree avecques les poulains. Si me manda messires Pierres d'Avallon que je me deffendisse vers ceux qui m'apeloient poulain et lour deisse que j'amoie miex estre poulins que roncins recreus, aussi comme il estoient" (Joinville, Histoire de Saint Louis, $\mathbf{9 4 3 5}$, Wailly, quoted by F. Godefroy, op. cit., under poulain). Paisans should be understood as "natives," not necessarily as "peasants"; clearly Joinville is enjoined to defend both himself and poulains out of the belief, based on obvious popular etymology, that the term means "colt," which he contrasts with the "tired-out work horse." Medieval Frenchmen often indulged in popular etymology, sometimes with ironic intent (cf. Montjoie interpreted as "joy-giving" in Gir. de Ross., 3717, Mignard; see H. Diament, La légende dyonisienne et la juxtaposition des toponymes Montjoie et Saint-Denis..., in Romance Notes, Vol. XIII, Number 1, 1971). The term is also used derogatorily in Gestes des Chiprois: "Lors corurent chevaliers et sergens, et les polains dou port as barches et as autres petits vaisseaux que il troverent au port et vendrent as assalandres" (Geste des Chiprois, p. 96, Raynouard, quoted by F. Godefroy, op. cit., under poulain). This interpretation is also that of J. Prawer: “...gens des classes inférieures” (Histoire...op. cit., Vol. II, p. 245, note 44). The context clearly distinguishes the "harbor Poulains" from both knights and foot soldiers. The "Oath of the Poulains" mentioned by Prawer (ibid.) confirms this impression. The events described are dated 1232 or shortly thereafter, some 40 years before Joinville's statement, itself written in his old age (1309) and quoted from memory. It may be doubted that the Sire de Joinville would have even indirectly defended the Poulains with such vigor, or recommended that the king dwell with them (in spite of Louis IX's well known piety) had he thought that the term referred exclusively to the native Christian inferior classes. And so, while accepting the derogatory use of the term in the thirteenth century, it may be asked whether it meant only the Poulain plebeians and not the Poulains as a whole, as it had in the twelfth century. Specification of "harbor" or "commune" in the case of the Oath would tend to cast doubt on universal opprobrium within Oultremer though it could be such in the eyes of some aristocratic new French arrivals who might look down on even their "colonial" fellow lords: "Malgré li Polein aurons nous roi Poitevin" said Guy de Lusignan, who came from Poitou (Prawer, Histoire..., Vol. I, p. 636).

${ }^{47}$ Historians have been a bit harsh on the intellectual contribution of the Crusader kingdoms, e.g., "Très secondaire est le röle de la frange chrétienne des ètats latins d'Orient. Ce front de rencontre entr e l'Occident et l'Islam est avant tout un front militaire, d'opposition armée, le front des Croisades. Echange de coups, non d'idées et de livres. Rares sont les oeuvres qui filtrent à travers cette frontière de combats." (J. LeGoff, Les intellectuels au Moyen Age [Paris, 1967]. p. 19). Given the circumstances we find J. Prawer expressing more fairness by reminding us of the essential contribution of Crusader French jurists, such as Jean d'Ibelin, the author of the Assize of Jerusalem, admittedly only interested in the conservation of feudal privileges: “...sa création culturelle la plus originale, les ouvrages des juristes..." (Histoire..., Vol II, p. 3). Even military fronts, if protracted, can serve cultural osmosis; witness the Reconquista in Spain, and the Crusader establishments were no exception in that they transmitted both 
et le clergé latin devait prêcher dans ces langues." 48 There is no good reason to suppose that the situation was substantially different in the Kingdom of Jerusalem itself. Much has been made by intellectual historians of the fact that in the medieval West knowledge of the Greek language had been lost (Graecum est, non legitur!) until the fall of Constantinople in 1473 drove many Byzantine scholars to Italy at the dawn of the Renaissance. One may well ask: how is it that the direct exposure of substantial numbers of Western, Roman clerics to Greek in the Middle East as well as in Byzantium and Greece themselves, all through the medium of the Crusades, was not accompanied by a significant revival of Greek studies as early as the twelfth century? Whatever the answer to that question there is no denying the reality of Greco-Latin symbiosis in and around Palestine. Clerical bilingualism and plurilingualism might provide a clue to the origin of Poulain more plausible than traditional explanations: The same Greek toponymic root polis, in its derived, Latinized, patrial form, well attested since Antiquity, -POLITANUS "citizen, subject or member of the city, polity or group" may well be the sought-for etymon here as in the case of turcople. While usually attached to another onomastic or non-onomastic root in a patrial combination (cf. GRATIANOPOLITANUS, NEAPOLITANUS, etc.) there is no reason to exclude the possibility of its having sprung up and been used independently here and there in the Romania in a more popular form, as the second member of a doublet, the learned member of which continued to be in French the bound morpheme -politain and the popular one the free morpheme *poulain. This description of hypothetical events certainly fits the facts semantically and historically. As for the phonological evolution of POLITANU(M)>poulain, that would not seem to present any major obstacles. Indeed one possible reconstructed sequence would bear a certain initial resemblance to the one that was submitted for the attested-POLITANU(M) $>$ -vaudan process supra: (Graphemic transcription) PÒLITÁNUM $>$ PÒLITÁNU $>^{*}$ pòlidán $>$ poldán $>{ }^{*}$ pollain $>$ polain $>$ poulain (the fifth step, in which -ld- $>-11-$ may be explained by progressive assimilation).

This reconstruction (or variants thereof in the intermediate unattested steps) accounts for the historical phonetic evolution if the process was truly popular and took several generations to complete. But what has been seen of Betenopolis and Betenoble points to the possibility that the process, rather than being truly phonological, might have been an analogical one skipping most if not all of the steps and resulting in a direct translation into the French vernacular of a clerical POLITANU(M) as Poulain. Eight hundred years before Ausnahmslosigkeit clerics may not have been aware of the laws of sound change but they seem to have been quite aware of analogy, models and intuitive sets of correspondences. And so either they themselves created poulain for popular consumption, and their innovation spread as it filled a semantic need to designate a new breed of

Islamic and Byzantine elements of civilization to a hitherto rather primitive medieval West just emerging from the Dark Ages. J. Prawer has further elaborated on this point in his English-language work, The Latin Kingdom... .

${ }^{48}$ Histoire..., Vol. I, p. 666. 
Franks; or else the sequence was short-circuited by popular etymology and analogy in one or two generations on the model of either polain "colt" or patrial Poulain "Pole." 49

It might be added that at least one alternate Latin patrial did exist in Europe, also derived from polis, so that there was nothing holy about -POLITANUS even in Latin, the root / pol/ being the primary consideration for clerics: The city of Würtzburg in Germany finds its name clerically translated, literally and etymologically (whether the etymology be real or fancied as regards the first, determinant element of the place-name) as HERBIPOLIS ${ }^{50}$ as early as the twelfth century but the patrial is not the expected regular *HERBIPOLITANUS but rather HERBIPOLENSIS as attested in the expression Annales Herbipolenses. ${ }^{51}$ In this case we see yet another repatrialization, reminiscent of the replacement of incipient *Grenopolitain by Grenoblois, one quite legitimate onomastically since Latin -ENSIS, -ENSEM was much used for patrials. It is also a pure clerical replacement since popular development is quite absent from this Germanic event and HERBIPOLENSIS obviously never even started competing with the popular, spoken German patrial Würtzburger.

One might end by remembering the further quasi-toponymic analogical model of the ecclesiastical title métropolitain, first attested in French only in 1327,52 but already well attested in Vulgar Latin, in the derived patrial form METROPOLITANUS, itself borrowed and derived from Greek metropolis "mother city." This was also used in legal Vulgar Latin ${ }^{53}$ and yielded learned French métropole, attested from the fourteenth century54. As a learned word it did not undergo phonological erosion to go on to a popular * métrople as it might have if it had functioned as a real toponym in popular constant use.

As no one really knows, nor can one, the exact details of a psycholinguistic creative process that went on between eight hundred and a thousand years ago, one must of course be careful in the evaluation of any etymological hypothesis. Any number of factors may have been at work, singly, in partial combination, collectively, converging or diverging. It is believed, however, that a fundamental Greek root $/ \mathrm{pol} /$, actualized in a twin set of etyma, borrowed Greek -polis for turcople and Latinized derivative POLITANU(M) for poulain, a) establishes a

\footnotetext{
${ }^{49} \mathrm{Greimas}$, op. cit., p. 500, s.v. polain, fourth entry, says that as a patrial "Pole" the word is attested for the first time in 1360 in Froissart. But there is at least one attestation a full century earlier in Brunetto Latini's Li livres dou Tresor, in which Poland is called "la terre as poulains" (Critical Edition by F.J. Carmody, [Berkeley and Los Angeles, 1948], p. 117). It must have escaped the notice of Greimas, since he lists Brunetto Latini's work as one of his sources for his Dictionnaire... p. XI).

${ }^{50}$ Encyclopaedia Britannica, Vol. XXIII, s.v. Würtzburg.

${ }^{51}$ Pertz Edition, in Momumenta Germaniae Historica. Scriptores., XVI, 3. (1826 sqq).

${ }^{52}$ As adjective in J. de Vignay (Dauzat-Dubois-Mitterand, op. cit., s.v. métropole, p. 462). As noun, first attested in 1431 (Bloch \& Wartburg, op. cit., under métropole, p. 406).

${ }^{53}$ Dauzat et al., loc. cit.

${ }^{54}$ Ibid., in Chronique de Saint-Denis, an ecclesiastical source.
} 
possible link between two lexemes not previously linked, b) accounts for the totality of known facts in a manner more complete and more economical than previous theories, while respecting the data and canons of history, historical phonology, dialectology, toponomastics, semantics, graphemics, linguistics and Völkerpsychologie, and c) establishes strong presumption for the toponymic origin of both lexemes, through a consideration of their function as patrials.

The etymologist, who does not deal with an exact science, mechanists notwithstanding, must remain circumspect, and the toponymist, as an etymologist-plus, even more so. And so the root poulos cannot be entirely disregarded as a possible etymon for turcople, perhaps even for poulain. Both its phonology and its semantics are distantly but perceptibly related to polis. It is not impossible that poulos may have had a budding existence in connection with our two forms and have subsequently fallen into the attractive orbit of similar polis. Such a consideration is, strictly speaking, outside the scope of this paper, but it underlines the complexity of the problem and opens yet one more avenue of research into it. Two final examples of such avenues can be adduced: a) it is rather noteworthy that the attested Latinized form TURCOPOLUS, $-\mathrm{I}^{55}$, if used in the locative (ablative) plural (a well known Gallo-Roman place-naming pattern proceeding from patrial to toponym ${ }^{56}$ ), becomes (IN) TURCOPOLIS,

\footnotetext{
${ }^{35}$ See Du Cange, Glossarium mediae et infimae Latinitatis, Vol. VIII (Graz, 1954 reprint), s.v. TURCOPULI. Curiously, at least two Latin-language medieval chroniclers quoted by Du Cange consider the Turcoples to have been half-breeds (cf. the original semantics of Poulains): a) Albertus Aquensis, in Mardrinus, Lib. 5, cap. 3: "Turcopoli gens impia et dicta Christiana nomine, non opere, qui ex Turco patre et Graeca matre procreati..."; b) Ramundus de Agiles: “...qui vel nutriti apud Turcos, vel de matre Christiana, patre Turco procreantur..." (no exact references given). If we are to believe these definitions the Turcoples were, as it were, almost mirror images of the Poulains, who had a Christian Frankish father and a Syrian mother, though the latter was Christian. Old French sources, however, do not speak of Turcoples as mestizos, or even as Christians, though no doubt some may have been. Albertus Aquensis is Albert d'Aix, author of Liber Christianae expeditionis pro ereptione emundatione Sanctae Hierosolymitanae ecclesiae (in Recueils des Historiens des Croisades, Historiens Occidentaux, 5 vols., Vol. IV). Ramundus de Agiles is Raymond d'Aguilers, Historia Francorum qui ceperunt Hierusalem (ibid., Vol. III). The Recueil was published in Paris between 1841 and 1906 by the Académie des Inscriptions et Belles-Lettres. Du Cange himself supplies the traditional poulos etymology which he traces "apud Graecos recentiores." At any rate, both chroniclers of the early crusade use the word as a patrial, not in the sense of "lightly armed soldier," further proof that the patrial meaning preceded semantic specialization. Du Cange adds: "Nempe quasi Turcorum filii...." Modern lexicographers have not retained the half-breed meaning for Turcople though they have for poulain. Early meanings may however be of significance to historians, and neither word should be treated as if its semantics were fixed and immutable: the latter was no more so than its phonology or orthography. Cf. H.B. Mayer, The Crusades (New York \& Oxford, 1972, transl. by J. Gillingham) who says of Turcopoles that "They were mostly baptized Muslims..." (p. 164), and that poulains were "half-castes...the children of Turkish-Greek or FrankishSyrian marriages"(p. 153), apparently confusing them in part with the Turcopoles as defined by Albert d'Aix. ${ }^{56}$ E.g., (IN) REMIS $>$ Reims (Rheims in the English spelling.) See W.v. Wartburg, Evolution et structure de la langue française 7th ed., revised (Bern, 1965), p. 25, for additional examples and an explanation of the patrial-totoponym process. Since the opposite process also exists, we can speak of a kind of osmosis paralleling the well-
} 
phonetically and semantically exactly the same as our proposed etymon; b) the earliest Latin attestation of poulains, Suger's polini, is a nominative plural whose root-morpheme coincides exactly with the accusative singular of Greek polis, that is, polin. And thus would several roads appear to lead to polis, via Jerusalem and Rome.

University of Haifa

known anthroponymic-toponymic one. Romance Onomastics thus exhibits historical multiple reversibility, a picture of which can be schematically summarized as follows:

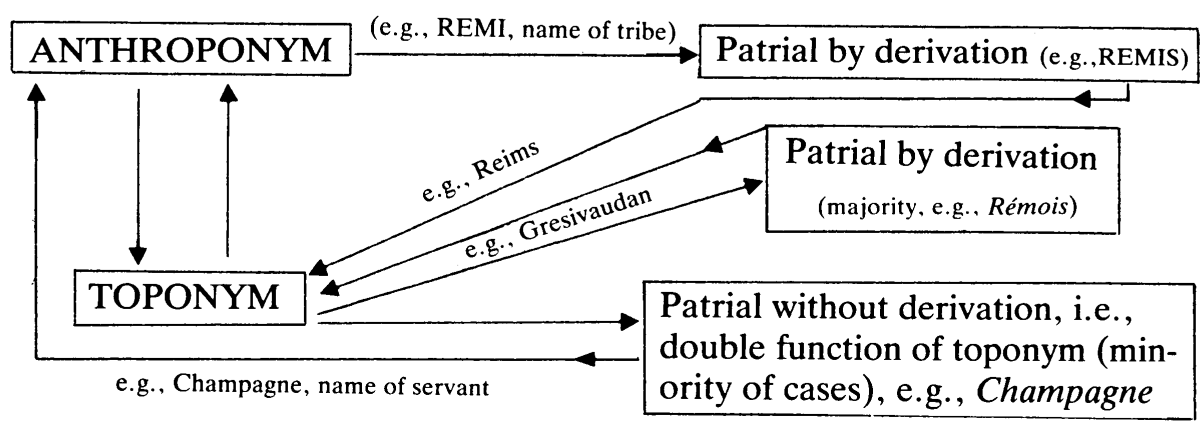

